\title{
ICT as a Tool to Foster Teaching and Learning in Nigeria
}

\author{
A. G. Salihu and N.S. Umar
}

\begin{abstract}
Advancement in technology has brought about information technology. Information and communication technology (ICT) has changed the methods of carrying out activities in different areas of human endeavours. As a result of the world rapidly adopting digital media and information, the roles of ICT in assuring quality education is becoming important and the importance is expected to continue growing. In this paper, the effectiveness of adopting ICT as a tool for Teaching/Learning Processes and academic performance was investigated and issues militating against integration of ICT were reviewed. A total of 90 questionnaires were administered to respondents who were students selected randomly from three polytechnics in Nigeria. The selected students were classified into experimental group (learning using ICT) and control group (learning without ICT). Interviews were also employed for selected lecturers. The results show that the use of ICT as a tool for learning has improved the learning outcome of the selected students and the use of ICT for teaching has made teaching very interesting to students with consequential increase in performance of students. Integration of ICT into Teaching and Learning is considered to be a necessary issue for students, educators and education administrators to assure better understandings and effective teachings.
\end{abstract}

Index Terms- Learning, Teaching, ICT, Learning Management System.

\section{INTRODUCTION}

Although Information and Communication technology (ICT) has been viewed by authors in different ways but in the context of this paper a definition adopted by [1] would be used. ICT is used as an umbrella term that includes any communication device or application, encompassing: radio, television, cellular phones, computer and network hardware and software, satellite systems, as well as the various services and applications associated with them, such as videoconferencing and distance learning. ICT, in education, is also construed in the particular context of ICT provision, policy and teacher factors that variously support teaching, learning and a range of activities in education.

Advancement in technology, especially ICT, has revolutionized many areas of human endeavours. Integrating ICT into teaching and learning seems to be a necessary issue to academic institutions nowadays. [2] points out that Information and Communication Technology should thus be used as tools to facilitate thinking and knowledge construction. Useful roles for technology to support effective pedagogy include as pointed out by [3] are as

Published on July31, 2020.

A. G. Salihu, Umaru Ali Shinkafi Polytechnic, Sokoto

(corresponding e-mail: salihu_ganiyu@yahoo.com)

N. S. Umar, Umaru Ali Shinkafi Polytechnic, Sokoto.

(e-mail: nurasidiumar@gmail.com) follows:

Technology as tools to support knowledge construction: For representing learners' ideas, understandings, and beliefs and producing organized, multimedia knowledge bases for learners.

Support learning-by-constructing: For accessing needed information, comparing perspectives, beliefs, and world views.

Technology as context to support learning-bydoing: For representing and simulating meaningful realworld problems, situations and contexts as well as representing beliefs, perspectives, arguments, and stories of others for defining a safe, controllable problems space for student thinking.

Technology as social medium to support learning by conversing: For collaboration with others, discussing, arguing, and building consensus among members of a community and supporting discourse among knowledgebuilding communities.

Technology as intellectual partner to support learning-by-reflecting: For helping learners to articulate and represent what they know for reflecting on what they have learned and how they came to know and constructing personal representations of meaning for supporting mindful thinking. knowledge.

Technology as information vehicles for exploring

For integration of ICT into education to be successful, there must be careful planning which depends largely on how well policy makers understand and appreciate the dynamics of such integration. Despite the fact that Nigerian government has been promoting the use of ICT in tertiary institutions through series of ICT Policies, programmes and interventions, there are challenges and barriers which contribute to the inefficient use of ICT in teaching and learning processes. Lack of effective implementation of ICT policies, inadequate trainings of Lecturers and Students in ICT use in education, ICT infrastructural deficiencies or inadequacies and cultural problems [3].

It is considered that the research will potentially be of considerable importance, for a number of reasons:

- To support policy makers in education and other related agencies in Nigeria in appreciating the need for the use of ICT in education institutions.

- To provide a set of guidelines to policy makers for the successful integration of ICT into teaching and learning

- To support educational administrators and policy makers in choosing the appropriate methods of managing changes associated with ICT use in the educational system in Nigeria. 


\section{BACKGROUND}

In Conventional teaching and learning, there have been emphasis on content and for many years, courses have been written around textbooks Teachings had been carried through lectures and presentations intermingled with tutorials and learning activities designed by teachers to enhance and rehearse the content. Modern-day settings are now favouring curricula that promote competence and performance. Educational Curricula have begun to emphasize capabilities and to be concerned more with usage of information than with what the information is. Contemporary ICTs are able to provide enabling environment that offer strong support for all these requirements and there are now a great number of outstanding examples of world class settings for competency and performance-based curricula that make sound use of the affordances of these technologies [4].

[5] opine that Technology has been identified to be playing an increasingly significant role in people's lives, and it is envisaged that usage of technology and its associated knowledge will soon become functional requirement for people's work, social, and even personal lives. Both social and economic factors dictate that students will need computer and communication technology skills if they are to live successfully in a knowledge-based era. Therefore, Information and communication technology (ICT) has become commonplace entity in all spheres of life.

ICT in [6] has been found to have fundamentally transformed the practices and procedures of nearly all forms of endeavour in different sectors. Education has been regarded as socially oriented activity and, therefore, quality education has traditionally been associated with strong teachers having high degrees of personal contact with learners. However, with the support of ICT, education has lent itself to more student-centered learning settings.

Three components of technology enhanced learning environment are identified in [5] as Pedagogy, social interaction and technology. A careful design of these components should enable teachers to integrate ICT into teaching and learning in an effective way. Naturally, pedagogy and social interaction are the central focus of a learning environment, and technology provides essential support.

[4] further stated that adoption and use of ICTs in education have a positive impact on teaching, learning, and research. ICT can affect the delivery of education and enable wider access to it. Furthermore, it makes education very flexible so that learners can access the education without barriers of time and geographical locations. It influences the way students are taught and how they learn. It would provide the rich environment and motivation for teaching learning process which seems to have a profound impact on the process of learning in education by providing new possibilities for learners and teachers. These possibilities can be applied in education by providing new possibilities for learners and teachers. These possibilities can have an impact on students' performance and achievement. Similarly wider availability of best practices and best course material in education, which can be shared by means of ICT, can foster better teaching and improved academic achievement of students.

ICTs have been recognized to be exerting impacts on pedagogical approaches in the classrooms. Their identified contributions to changes in teaching practices, school innovation, and community services are remarkable. A research reported in [7] suggests three significant concerns of consideration regarding ICTs impact on education. Firstly, student performances such as higher scores in school subjects or the learning of entirely new skills needed for a developing economy. Secondly, we should consider teacher and classroom outcomes such as development of teachers' technology skills and knowledge of new pedagogic approaches as well as improved attitudes toward teaching and learning. Finally, one has to consider other outcomes such as increased innovativeness in schools and access of community members to adult education and literacy.

With particular reference to developing countries, [7] opines that "Developing countries usually tend to be at the undesirable end of the digital divide spectrum. However, they cannot afford to stay passive and be left behind in race for better social, economic and education prospects."

\section{Materials AND Methods}

Considering the general objective of investigating the effectiveness of use of ICT as a tool to foster teaching and learning, the chosen method is mixed research methodology. This methodology is employed in this study, because it balances the strengths and weaknesses of both quantitative and qualitative research [8]. There are many advantages to using a mixed method approach for this particular research focus, which investigate the effectiveness of ICT to foster teaching and learning. This mixed method approach provides the best opportunities for the research problems of this study, the answers of which rely upon a variety of forms of data. The quantitative section, which includes questionnaires, addresses factors relating to how effective ICT is related to teaching method of lecturers and learning outcomes of students. The qualitative section includes interviews. The students were equally observed using their computers and hand held ICTs facilities in learning.

There are many important research methods employed by social researchers to secure the data needed to answer their research questions. All have their own strengths and weaknesses and are more or less, suited to different projects [8]. Two of the most commonly employed data collection methods are questionnaires and interviews, each of these provide an alternative tool for the collection of empirical data and allow the researcher to ascertain that data collected is suitable for the research [9].

Therefore, A total number of ninety (90) questionnaires were administered to respondents who were students selected randomly from three polytechnics in Nigeria. The polytechnic are Umaru Ali Shinkafi, polytechnic, Sokoto, Waziri Umaru Federal Polytechnic, Birnin-Kebbi and Kwara State Polytechnic, Ilorin. Thirty (30) students were selected from each of the polytechnics and the selected students were classified into experimental group (learning using ICT) and control group (learning without ICT).

Two lecturers with interests in teaching with ICT were selected from each polytechnic for interviews. The lecturers were introduced to four open-source Learning Management System (LMS) which were Moodles, Sakai, Desire-to-learn and Blackboard. It has been pointed out in [10] that the four LMS have the scalability and capacity to handle large-scale 
installations for high number of users.

The main traditional method of classroom teaching and learning was replaced by interactive software for individual work and for the interactive board by the use of projectors and Learning Management System Software. These new ICT tools provide very attractive graphics, high quality audio and video components and allow the teachers to create their own interactive teaching materials for students learning.

\section{RESUlts AND Discussion}

Questionnaires

As part of efforts to achieve the objectives of the research study, the data collected are presented and analyzed statistically to find out the effectiveness of ICT in fostering teaching and learning:

TABLE I: STUDENTS' PERFORMANCES BEFORE-ICT SESSION OF THE EXPERIMENTAL GROUP AND THE CONTROL GROUP

\begin{tabular}{|c|c|c|c|c|c|c|}
\hline ICT & $\begin{array}{c}\text { Class of } \\
\text { Group }\end{array}$ & No & Mean & Variance & $\begin{array}{c}\text { T- } \\
\text { Value }\end{array}$ & $\begin{array}{c}\text { Level of } \\
\text { Significance }\end{array}$ \\
\cline { 1 - 5 } Before & $\begin{array}{c}\text { Experimental } \\
\text { Group }\end{array}$ & 45 & 32.09 & 35.95 & & $\begin{array}{c}\text { Not } \\
\text { Significant } \\
\text { at } 0.01\end{array}$ \\
\cline { 1 - 4 } Before & $\begin{array}{c}\text { Control } \\
\text { Group }\end{array}$ & 45 & 34.22 & 26.22 & -1.82 & \\
\hline
\end{tabular}

The mean value of examination scores for the Experimental group was 32.09 and the mean value for the Control Group was 34.22 while the mean difference is 2.13 . The data analysis, employing $\mathrm{T}$-test showed that $\mathrm{t}$-value was -1.82 which implies that there is no significant difference in students' performance between the two groups in pre-ICT session. The t-value of -1.82 is less than the table values at 0.01 level of significance, hence, it can be inferred that there will be no significant difference in the student's performance before ICT integration session between the experimental and control groups. [11] pointed out that Teachers and Students should understand the basic issues (effectiveness, cost, equity, and sustainability), as well as the challenges (infrastructure related challenges, capacity building challenges, challenges related to financing the cost of ICT use, to mention but few) surrounding the use of ICT before applying them in teaching and learning.

TABLE II: STUDENTS' PERFORMANCES AFTER-ICT INTEGRATION SESSION

\begin{tabular}{|c|l|l|l|l|l|c|}
\hline ICT & $\begin{array}{c}\text { Class of } \\
\text { Group }\end{array}$ & No & Mean & Variance & $\begin{array}{c}\text { T- } \\
\text { Value }\end{array}$ & $\begin{array}{c}\text { Level of } \\
\text { Significance }\end{array}$ \\
\hline After & $\begin{array}{l}\text { Experimental } \\
\text { Group }\end{array}$ & 45 & 74.27 & 138.29 & 18.25 & $\begin{array}{c}\text { Significant } \\
\text { at } 0.01\end{array}$ \\
\hline After & $\begin{array}{l}\text { Control } \\
\text { Group }\end{array}$ & 45 & 39.69 & 23.31 & & \\
\hline
\end{tabular}

The mean value for examination score for the Experimental Group was 74.27 and the mean value for examination score for the Control Group, was 39.69. The data analysis, employing t-test analysis showed that the tvalue was 18.25 which is higher than the table value at 0.01 level of significance. These results show that there was significant difference in students' performances between both groups in post-ICT session hence it could be inferred that the significant difference in the students' performances in post-ICT session between the experimental group and control group was as a result of integration of ICT into teaching and learning. It can therefore be concluded that ICT use in teaching and learning processes improve student's performances greatly. [6] pointed out that an Effective integration of Information and Communication Technology (ICT) into teaching and learning will improve teaching and learning but however, teachers do not usually follow linear instructional design models when they are planning for ICT integration. He, therefore, proposes careful planning and designing of ICT integration for success to be achieved.

TABLE III: COMPARISON OF STUDENTS' PERFORMANCES BEFORE AND AFTER APPLICATION OF ICT TO EXPERIMENTAL GROUP

\begin{tabular}{|c|c|c|c|c|c|c|}
\hline ICT & $\begin{array}{c}\text { Class of } \\
\text { Group }\end{array}$ & No & Mean & Variance & $\begin{array}{c}\text { T- } \\
\text { Value }\end{array}$ & $\begin{array}{c}\text { Level of } \\
\text { Significance }\end{array}$ \\
\hline After & $\begin{array}{l}\text { Experimental } \\
\text { group }\end{array}$ & 45 & 74.27 & 138.29 & \multirow[b]{2}{*}{21.43} & \multirow[b]{2}{*}{$\begin{array}{l}\text { Significant } \\
\text { at } 0.01\end{array}$} \\
\hline Before & $\begin{array}{l}\text { Experimental } \\
\text { Group }\end{array}$ & 45 & 32.01 & 35.95 & & \\
\hline
\end{tabular}

The mean value for examination score for the Experimental Group was 74.27 after integration of ICT and the mean value for examination score for the Experimental Group was 32.01 before integration of ICT. The data analysis, employing t-test analysis showed that the t-value was 21.43 which is higher than the table value at 0.01 level of significance. These results showed that there was significant difference in students' performances of experimental group before and post-ICT session. Therefore, the significant difference in the students' performances of experimental group before and after ICT session was observed as a result of integration of ICT into teaching and learning. It can therefore be inferred that ICT use in teaching and learning processes improve student's performances greatly. [12] observe that the adoption and use of ICTs in schools have a positive impact on teaching, learning, and research but despite the roles ICTs can play in education, schools in Nigeria have yet to extensively adopt them for teaching and learning. They identified problems such as poor policy and project implementation strategies, and limited or poor information infrastructure as factors militating against these efforts of Nigerian Government.

\section{Interviews}

The selected participants for the interviews were requested to answer and respond to following short questions:

- How easy is the application of ICT in teaching?

- How efficient is the use of ICT in teaching?

- How attractive is presentation of lectures using ICT?

- How satisfied are the students with lectures employing ICT facilities?

- How effective is the learning outcomes?

In each of the case study, each of the lecturers was asked to give feedback on the ICT usage in enhancing teaching and learning on a scale of 1 (lowest) to 5 (highest). The table below provides the summary of results of each of the respondents (R1-R5). 
TABLE IV: RESPONSES ON ICT USAGE IN FOSTERING TEACHING AND LEARNING

\begin{tabular}{|l|c|c|c|c|c|c|}
\hline & R1 & R2 & R3 & R4 & R5 & R6 \\
\hline $\begin{array}{l}\text { How easy is the } \\
\text { application of ICT } \\
\text { in teaching? }\end{array}$ & 4 & 4 & 5 & 5 & 4 & 4 \\
\hline $\begin{array}{l}\text { How efficient is the use of ICT in } \\
\text { teaching? }\end{array}$ & 5 & 3 & 4 & 4 & 5 & 3 \\
\hline $\begin{array}{l}\text { How attractive is presentation of } \\
\text { lectures using ICT? }\end{array}$ & 4 & 4 & 4 & 4 & 5 & 4 \\
\hline $\begin{array}{l}\text { How satisfied are the students with } \\
\text { lectures employing ICT facilities? }\end{array}$ & 3 & 3 & 3 & 4 & 4 & 5 \\
\hline $\begin{array}{l}\text { How effective is the learning } \\
\text { outcomes? }\end{array}$ & 5 & 4 & 4 & 3 & 4 & 3 \\
\hline
\end{tabular}

Metrics developed for each Sub-Characteristics: Based on the table IV, metrics that will be used in determining the effectiveness of the use of ICT in enhancing teaching and learning are:

Ease of Use: Inputs: $\mathrm{A}=$ Score obtained. $\mathrm{B}=$ Total score.

Equation: $\mathrm{X}=\mathrm{A} / \mathrm{B} \quad \mathrm{X}=(4+4+5+5+4+4) / 30=0.9$

$$
\begin{aligned}
& \text { Efficiency: Equation: } X=\mathrm{A} / \mathrm{B} \\
& \mathrm{X}=(5+3+4+4+5+3) / 30=0.8 \\
& \text { Attractiveness: Equation: } \mathrm{X}=\mathrm{A} / \mathrm{B} \\
& \mathrm{X}=(4+4+4+4+5+4) / 30=0.83 \\
& \text { Effectiveness: Equation: } \mathrm{X}=\mathrm{A} / \mathrm{B} \\
& \mathrm{X}=(5+4+4+3+4+3) / 30=0.77
\end{aligned}
$$

All were found to be above average points of 0.5 and were considered acceptable.

\section{Conclusion And SugGestions}

Efficient and effective integration of Information and Communication Technology (ICT) into teaching and learning has been found out to be an integral part of modern education system and a new area to explore and exploit. This study has proven that the use of ICT in teaching and learning has improved the performances of students and the method is friendly, efficient, attractive, motivating and satisfactory. The comparison of students' performances has shown that the after integration of ICT, the performances of both Experimental and Control Group improved significantly. It can be, therefore, inferred from the study that there is a significant difference in performances of students based on varying variable of ICT.

Education reform has been discovered to be a recurring exercise throughout the world and one of major aspects of the reform is the introduction and integration of ICT in the education system. The successful integration of ICT, into our education system demands supports of policy makers and education administrators as well as that of students and teachers to understand and appreciate the dynamics of such integration.

Therefore, in order to make integration of ICT achieve the fostering of teaching and learning in Nigeria, infrastructural deficits should be addressed, teacher should be well trained and motivated, appropriate educational software and technical support should be provided, implementation of learner-centred instruction and proper assessment procedures should be established. A great deal can be learnt, however, from what developed countries have done to deal with their technology integration problems, and much can be applied to developing countries to assure that teaching and learning is friendly, effective, efficient, attractive as well as guaranty satisfactory students performances.

\section{ACKNOWLEDGMENT}

Our appreciation goes to the management of the Umaru Ali Shinkafi Polytechnic, Sokoto and TETfund for facilitating the research. Our families and relations are also commended for their relentless support and tolerance during the course of the research.

\section{REFERENCES}

[1] O. Okorafor, "Pedagogical use of ICT in science education: the constructivist," November 2011.

[2] O. Jennifer et al., "An Analysis of e-Learning Impacts \& Best Practices in Developing Countries," Michigan State Univ., p. 64, 2011.

[3] S. Hennessy, B. Onguko, D. Harrison, E. Kiforo, S. Namalefe, and A. Naseem, "Developing the Use of Information and Communication Technology to Enhance Teaching and Learning in East African Schools: Review of the Literature," 2014.

[4] S. Noor-Ul-Amin, "An Effective use of ICT for Education and Learning by Drawing on Worldwide Knowledge , Research , and Experience: ICT as a Change Agent for Education," Dep. Educ. Univ. Kashmir, vol. 1, no. 1, pp. 1-13, 2013.

[5] R. B. Danner and C. O. A. Pessu, "A survey of ICT competencies among students in teacher preparation programmes at the university of Benin, Benin city, Nigeria,” J. Inf. Technol. Educ., vol. 12, no. 1 , pp. 33-49, 2013.

[6] Q. Wang, "A generic model for guiding the integration of ICT into teaching and learning," Innov. Educ. Teach. Int., vol. 45, no. 4, pp. 411-419, 2008.

[7] V. Jhurree, "Technology integration in education in developing countries: Guidelines to policy makers," Int. Educ. J., vol. 6, no. 4, pp. 467-483, 2005.

[8] D. Brink, "Essentials of Statistics": Exercises Download free books at Statistics - Exercises. 2010

[9] M. K. Syed, "Methods of data collection," Plast. Surg. Nurs., vol. 14, no. 2, pp. 109-110, 1994.

[10] A. G. Salihu and N. S. Umar, "Review of E-Learning Tools in Education,” Int. J. Bus. Adm. Manag. Res., vol. 2, no. 2, pp. 1-5, 2016.

[11] F. O. Esoswo, "Issues and Challenges in The Use of Information Communication Technology (ICTs) In Education” J. Inf. Knowl. Manag., vol. 20, no. 4, pp. 99-102, 2011.

[12] E. E. Adomi and E. Kpangban, "Application of ICTs in Nigerian Secondary Schools," Libr. Philos. Pract., vol. 2010, no. MAR, pp. 1$8,2010$. 